\title{
Paleontology in Argentina: History, heritage, funding, and education from a southern perspective
}

\author{
Diana Elizabeth Fernández, Leticia Luci, Cecilia Soledad Cataldo, \\ and Damián Eduardo Pérez
}

\section{BRIEF SUMMARY OF THE HISTORY OF PALEONTOLOGY IN ARGENTINA}

“(...) y siendo estos monumentos un testimonio auténtico y demostrable de que en la antigüedad hubo en esta región americana, sea antes o pos el diluvio, racionales gigantes (...)"

....and these monuments are an authentic and demonstrable testimony that in antiquity there was in the American region, either before or after the Flood, giant rational beings...

Translated from a letter by Esteban Álvarez del Fierro to the then Buenos Aires mayor, about his discoveries in Arrecifes (Gutiérrez, 1866).

There is a long tradition of paleontological research in Argentina. In 1766 Esteban Álvarez del Fierro reported the first fossils found in Argentinian territory, from Arrecifes, Buenos Aires province. Through the following years, large mammals were discovered in Luján and other nearby localities, and were sent to Spain for examination (Schávelzon and Arenas, 1992). These were mainly remains of Megatherium (Figure 1.1). Between 1833 and 1835, during his famous voyage on the H.M.S. Beagle, Charles Darwin visited several Argentinian localities, where he collected numer-

Diana Elizabeth Fernández. Instituto de Estudios Andinos Don Pablo Groeber (UBA - CONICET). Departamento de Ciencias

Geológicas, Facultad de Ciencias Exactas y Naturales, Universidad de Buenos Aires. Intendente Güiraldes 2160, Pabellón 2, C1428EGA, Ciudad Universitaria, Buenos Aires, Argentina. elizabeth@gl.fcen.uba.ar, arkhamdryad@gmail.com

Leticia Luci. Instituto de Estudios Andinos Don Pablo Groeber (UBA - CONICET). Departamento de Ciencias Geológicas, Facultad de Ciencias Exactas y Naturales, Universidad de Buenos Aires. Intendente Güiraldes 2160, Pabellón 2, C1428EGA, Ciudad Universitaria, Buenos Aires, Argentina. leticialuci@gl.fcen.uba.ar

Cecilia Soledad Cataldo. Instituto de Estudios Andinos Don Pablo Groeber (UBA - CONICET). Departamento de Ciencias Geológicas, Facultad de Ciencias Exactas y Naturales, Universidad de Buenos Aires. Intendente Güiraldes 2160, Pabellón 2, C1428EGA, Ciudad Universitaria, Buenos Aires, Argentina. ceciliacataldo@gl.fcen.uba.ar Damián Eduardo Pérez. Museo Argentino de Ciencias Naturales Bernardino Rivadavia, División Paleoinvertebrados, Av. Ángel Gallardo 470, C1405DJR, Buenos Aires, Argentina.dperez@macn.gov.ar

Keywords: Argentina; Argentinian Paleontological Association; Paleontology Degree; Paleontological Heritage; Outreach; Grants and Employment

Fernández, Diana Elizabeth, Luci, Leticia, Cataldo, Cecilia Soledad, and Pérez, Damián Eduardo. 2014. Paleontology in Argentina: History, heritage, funding, and education from a southern perspective. Palaeontologia Electronica 17.3.6E;1-18; palaeo-electronica.org/content/2014/1003-comment-paleontology-in-argentina 


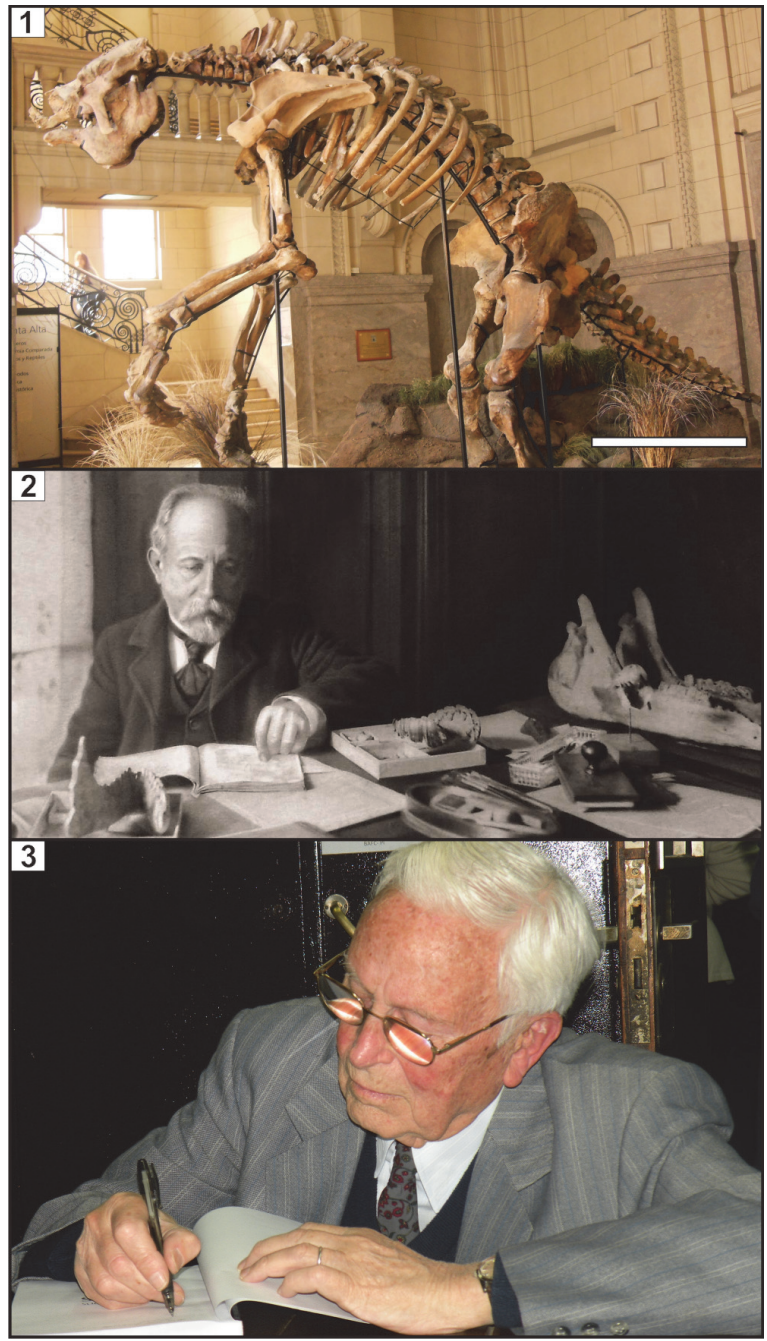

FIGURE 1. 1. Original skeleton of Megatherium americanum Owen displayed in the Bernardino Rivadavia Museum of Natural Sciences (MACN). Graphic scale = $1 \mathrm{~m}$. Photo courtesy of Marcelo Miñana. 2. Florentino Ameghino in his study. Taken from Fernícola et al. (2011). 3. Horacio H. Camacho in the presentation of the book Los Invertebrados Fósiles in 2008. Photo courtesy of Mónica Longobucco.

ous fossils and made important geological observations (Aguirre-Urreta et al., 2009). Many of these fossils were studied by European researchers such as Edward Forbes, G. B. Sowerby, and Richard Owen (Darwin, 1846). These studies, together with the observations made by other European naturalists, for instance Alcide d'Orbigny (d'Orbigny, 1842), constituted the basis for the emergence of paleontological knowledge of the region. Many of the materials collected in this period remain in foreign institutions such as the Natural History Museum, London.
In the later nineteenth century came the first discoveries and studies by native Argentinians, including Francisco Muñíz and Florentino Ameghino (Figure 1.2). The latter is considered as the founding father of Argentinian paleontology, being the first to engage in the professional study of Argentina's fossils. Ameghino was a contemporary of an important group of foreign-born researchers who came to the country driven by the emergence of Argentinian scientific institutions; this group included Hermann Burmeister, Auguste Bravard and Pellegrino Strobel.

Among the different paleontological disciplines, vertebrate paleontology is the one with the longest history in Argentina, represented by the previously mentioned observations of Muñíz, succeeded by the works of Burmeister and Bravard (Reig, 1961). This was followed by the great works of Ameghino, that included studies on fossil mammals as well as evolutionary, geological and biogeographic analyses (for a full review, see Fernícola et al., 2011). The diversity of studies increased in the late 1930s, with the emergence of native researchers such as Lucas Kraglievich, Carlos Rusconi and Ángel Cabrera, as well as the work of foreign paleontologists George Gaylord Simpson and Friedrich von Huene. In the second half of the twentieth century, key studies on dinosaurs were made by evolutionary biologist Osvaldo Reig and then by José Bonaparte. Recent decades of fossil vertebrate studies in Argentina have produced a generation of researchers who expanded knowledge of the field and achieved renown for their findings in local units (Pascual, 1981; Tonni, 2005).

The earliest geological studies of Argentina included descriptions of fossil plants, for example by d'Orbigny and Darwin (Ottone, 2005, 2011). A fossil trunk reported by Félix de Azara in 1809 is considered to be the first record of fossil plants in the country (Ottone, 2001). The formal beginnings of paleobotany took place during the last decades of the nineteenth century. Palynology began its development in the 1950s, with the advent of the appropriate techniques and methodology (Archangelsky, 2005). Some of the main contributors were Federico Kurtz, Joaquín Frenguelli, Carlos Menéndez and Sergio Archangelsky.

Some of the earliest mentions of fossil invertebrates in the country were once again by d'Orbigny and Darwin, with the material being studied by Sowerby. The work of Carl Gottsche on the Jurassic fauna of Paso del Espinacito (San Juan province) in 1878 represents the first formal research 
on local invertebrate fossils (Riccardi, 1981). In the 1880 s and 1890s the number of studies increased notably, including the results of several expeditions to Argentina by European and American scientists (e.g., Otto Nordenskjöld, John B. Hatcher, Gustav Steinmann). The contributions of Hermann von Ihering in the early twentieth century are also worth mentioning. As early as the 1920s and 1930s, the work of local researchers begun to gain notice, with the studies by Martín Doello Jurado (Aguirre-Urreta and Camacho, 2011) and Horacio Harrington as a starting point (Harrington, 1937; Riccardi, 1981, 2005). An important landmark was the publication of the book Fossil Invertebrates (Invertebrados Fósiles) by Horacio Camacho (1966). An updated and expanded second edition appeared in 2008 (Camacho and Longobucco, 2008; Figure 1.3). For further details on recent history, see Riccardi (2005), who compiled a group-by-group revision of local research during the last century, including contributions in micropaleontology and ichnology.

\section{NATIONAL SCIENCE POLICY AND FUNDING}

In a way, the development of paleontology in Argentina goes hand in hand with the political and economic history of the nation itself. In order to understand the current status of paleontology in the country, it is necessary to mention some general characteristics of science policy and funding in Argentina. Most of the scientific research done in Argentinian universities and institutes (whether public or private) is funded, directed and/or coordinated by government agencies. The scientific and technological progress of the country is currently considered as a national priority (H.C.N.A., 2001; MECT, 2006). This was not always the case, especially during the 1990s. In 2007, the Science, Technology and Productive Innovation Ministry or MINCyT (Ministerio de Ciencia, Tecnología e Innovación Productiva) was created, with the intention to place science and technology in the service of the economic and social development of the country (H.C.N.A., 2007). A special program was developed to facilitate, among other things, the return of Argentinian researchers working abroad (H.C.N.A., 2008).

CONICET, an independent organization under the jurisdiction of the MINCyT, is the main institution that promotes science and technology in the country (P.N.A., 1996, 2007). The acronym CONICET stands for Consejo Nacional de Investigaciones Científicas y Técnicas (National Scientific and Technical Research Council). Some of its main objectives are: 1) the funding and support of scien- tific and technological activities within the country through research grants and fellowships; 2) the organization and funding of institutes, laboratories and research centers; 3 ) the promotion of international cooperation; and 4) the administration of the Scientific Researcher Career (Carrera del Investigador Científico; $\mathrm{CIC}$ ) and the Personnel in Support of Research Career (Carrera de Personal de Apoyo a la Investigación y al Desarrollo; CPA) (P.N.A., 1996, 2007). Its academic activities are divided into four principal areas: 1) Agrarian Sciences, Engineering, and Materials Science; 2) Biological and Health Sciences; 3) Exact and Natural Sciences (excluding biology); and, 4) Social Sciences and Humanities. The board is integrated by a president and eight researchers actively involved in one of the previously mentioned four areas (P.N.A., 1996, 2007). The Exact and Natural Sciences Area includes approximately $26 \%$ of all CONICET researchers and $20 \%$ of its doctoral and postdoctoral fellows, and nucleates the following disciplines: Earth, Water and Atmospheric Sciences, Mathematics, Physics, Astronomy and Chemistry (G.R.H.-CONICET, 2012a, 2013). Paleontological research falls within the first subdiscipline.

Most Argentinian paleontologists work as CONICET researchers (see below). Apart from their salaries, CONICET researchers can apply for project funds. CONICET currently finances 34 projects of varied paleontological interest, representing $31 \%$ of the whole Earth sciences projects presently under execution (based on information provided by the Evaluation and Planification ManagementGerencia de Evaluación y Planificación-of CONICET).

Similarly to CONICET, the Agency of Scientific and Technological Promotion (Agencia Nacional de Promoción Científica y Tecnológica; ANPCyT), also funds numerous projects regardless of the institutional affiliation of the applicant. This nationwide financial source presents an even stronger presence of paleontology within the Earth sciences category; in the 2013 call for projects, ANPCyT financed 26 projects in assorted paleontological topics, resulting in $44.1 \%$ of all the Earth sciences projects. Of these, 15 projects were given to young researchers beginning their line of investigation; two went to recently formed research groups and nine to stable, pre-established research groups with a long tradition in their respective subjects. This indicates a strong presence of both new paleontologists as well as consolidated groups in which 


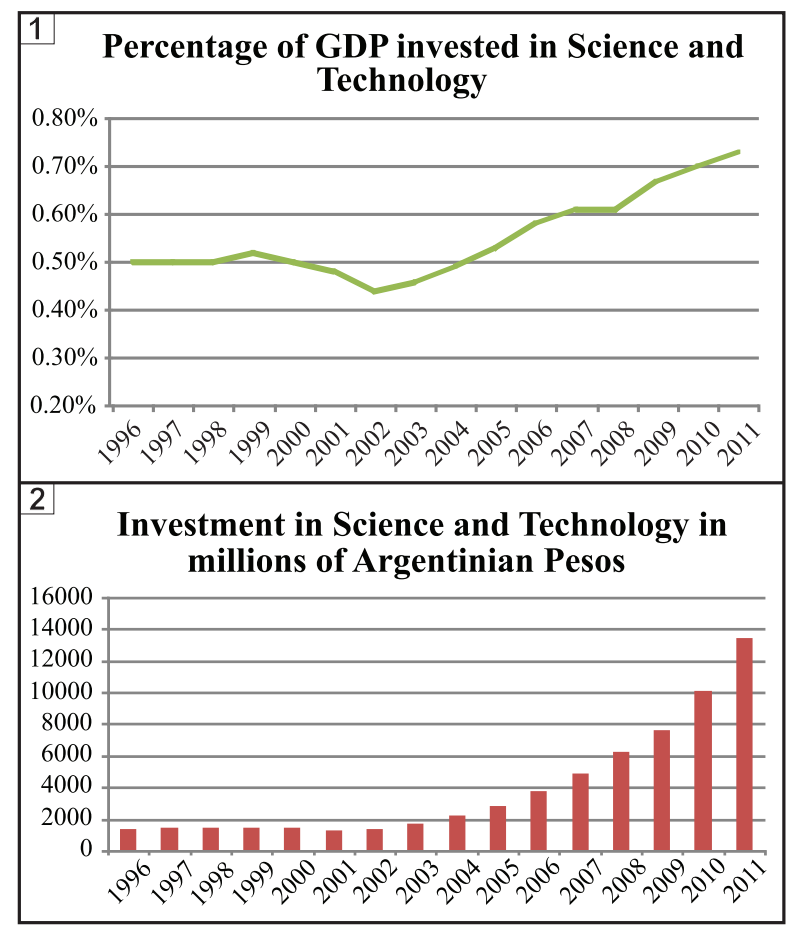

FIGURE 2. 1. Expenditure on scientific and technological activities in the period 1996-2011 expressed in percentage of the GDP. Source: MINCyT (2013). 2. Expenditure on scientific and technological activities in the period 1996-2011 expressed in millions of Argentinian Pesos. Source: MINCyT (2013).

several paleontologists, both seniors and young, collaborate.

Federalism of science and technology is mainly promoted through higher salaries and grants available for those researchers that plan on settling on academic institutions outside the main metropolitan areas in which most research centers are nowadays concentrated (CONICET, 2013). Between 2003 and 2012, the number of human resources (i.e., scientists, technicians and doctoral and postdoctoral fellows) in the city of Buenos Aires increased approximately $149 \%$. In the provinces of Buenos Aires, Córdoba, Santa Fe, Mendoza and the rest of the country, the increment has been of $162 \%, 195 \%, 159 \%, 139 \%$ and $166 \%$, respectively (G.R.H.-CONICET, 2012b). During the same time period, based on data published by the MINCYT, salaries of CONICET scientists increased by over $843 \%$. The real increment in salaries and budget is actually lower due to consumer price index $(\mathrm{CPI})$ variations. The magnitude of $\mathrm{CPI}$ variations since 2007 has been strongly debated in Argentina, since CPI values published by different private and public sources may be twice or more the values published by the official institute of statistics (INDEC) (H.C.D.N., 2009 to 2014; INDEC, 2014). Another indicator of the government's investment in research and development is the percentage of the gross domestic product (GDP) invested (GDP); it went from $0.42 \%$ in 1996 to $0.65 \%$ in 2011 , an increase of nearly $55 \%$ (Figure 2.1-2; MINCyT, 2013).

The presence of paleontological projects in different funding sources is quite important within the area of knowledge in which paleontology is included (usually Earth sciences). For example, of the research projects financed by the University of Buenos Aires (Universidad de Buenos Aires; UBA) within the engineering and environmental sciences area (which includes paleontology) in the last few years, $6.4 \%$ are projects involving a variety of paleontological aspects (invertebrate paleontology, micropaleontology, vertebrate paleontology, ichnology, etc.). These are, however, restricted to teachers within the university.

In comparison to previous decades, science in Argentina is going through a springtime period. Nevertheless, on a worldwide scale, the scenario is not ideal. Even with better salaries and more funding, Argentinian science is still disadvantaged when compared to developed countries (MINCyT, 2013). In those nations, over $65 \%$ of the funds invested on science come from private sectors (MINCyT, 2013), while in Argentina, which is a developing country, the main contributors are state organisms (MINCyT, 2013). Articulation between the research from public and private sectors has recently been prioritized but still remains at its initial stage (MINCyT, 2011).

Budgets are usually insufficient when supplies from abroad are needed or when traveling abroad is involved. These difficulties have been increased with the CPI variations, which coupled to the long time intervals between grant writing and submission and between submission and funding release, have resulted in original budgets always running short. In addition, the sums for scientific grants have only been updated this last call for proposals (Rocca, 2014), and restrictions and extra taxes are currently being applied to purchases in foreign currency (Wharton School, 2011; ANPCyT, 2014; World Review, 2014). For these reasons, most technological equipment and supplies are not easy to obtain. 


\section{CAREERS IN PALEONTOLOGY}

\section{Degrees}

Scientific careers in Argentina are usually structured in a five-year program, after which a graduate degree (called licenciatura) is obtained. Programs are commonly divided into two cycles: a three- to four-year-long core cycle, in which a number of general and basic subjects are taken; and a cycle of orientation (usually lasting one to two years), in which each student must choose a few elective subjects from a pool of different topics. Most science-oriented careers are offered only in public universities. In these, degrees are free and open and many different kinds of scholarships and grants are available, mainly from the government agencies and universities. All Argentinian universities mentioned here are public.

Paleontology as a subject can be found in the geology and biology programs of many universities. At least one course of paleontology is included within the geology program in most cases, while it is less common or elective in the biology degrees. Geology, biology and the recently created paleontology (see below) degrees in Argentina usually involve about 20-30 (or more, in some semesters) weekly hours of classes, on top of which the student must add the time it takes to prepare for class, make reports and study for exams. This presents a difficulty for those students who need to work to support their studies, commonly taking them a few more years to graduate.

Traditionally, people wanting to work as paleontologists obtained a degree in geology or biology, including as many paleontological topics as possible in their program. Only the National University of La Plata (Universidad Nacional de la Plata, UNLP) offered a biology degree with orientation to paleontology. No formal degree in paleontology existed until it was created a few years ago in the UBA. The latter is the most important university of the country regarding budget, academic offer and number of students (SIU, 2011; Top Universities, 2014); it has a number of faculties distributed across the city of Buenos Aires, and a variety of associated centers of research and education (Top Universities, 2014). In 2002, the degree in paleontology (Figures 3,4 ) was created within the Faculty of Exact and Natural Sciences (Facultad de Ciencias Exactas y Naturales; FCEN), becoming the first degree in paleontology in Argentina and Latin America. Shortly after, in 2009, the National University of Río Negro (Universidad Nacional de Río Negro; UNRN) also created a five-year degree in paleontology (Figure 3). Paleontology both in the UBA and UNRN cover invertebrate and vertebrate paleontology, micropaleontology, paleobotany, paleoecology, taphonomy and biostratigraphy as well as geologic and biologic subjects; both careers are strongly interdisciplinary. They differ somewhat on which subjects are elective and which are included as mandatory courses. Their curricula are also structured in a different way (Figure 3 ). In the UNRN there are more, shorter courses per semester, while in the UBA there are fewer but they have a greater load of class hours. Both programs require a degree thesis to graduate, as do many other science-oriented careers in the country.

The paleontology program in the UNRN offers an intermediate degree, a Diploma in Geosciences after the first two years of study, which are common to the geology degree and are thus more focused on general (mathematics, chemistry, physics) and geological subjects. From the third year on, the biological and paleontological subjects gain importance while maintaining some geological topics (Figure 3).

The degree in the UBA does not offer an intermediate title, and includes one extra year, the Basic Common Cycle (Ciclo Básico Común; CBC). This is composed of six subjects, some of which are common to all degrees from the UBA whilst others are general subjects varying according to the career. The CBC is compulsory and students must pass all six subjects in order to begin their degree studies (Figure 3).

Since it started functioning, the paleontology program in the UBA has had a small but steady flow of students. Around 10 students enrolled per year for the period 2003-2006, whilst for the 20072011 interval the enrollment increased to about 14-19 students, to later drop back to around 10 students per year (Figure 4.1). Since 2008, about 32 graduates have completed their paleontology studies in the UBA. Many of the initial difficulties have been removed while a few others are being worked on, but overall the career has had a successful start and will likely continue to improve.

The paleontology degree in the UNRN has had about 20 students beginning the course per year, including students from Bolivia and Chile. There are no graduates yet; the earlier students will be graduating this year (Casadío, personal commun., 2014).

Since for the last few years Argentina has been the only Latin American country with a degree in paleontology, foreign students are com- 


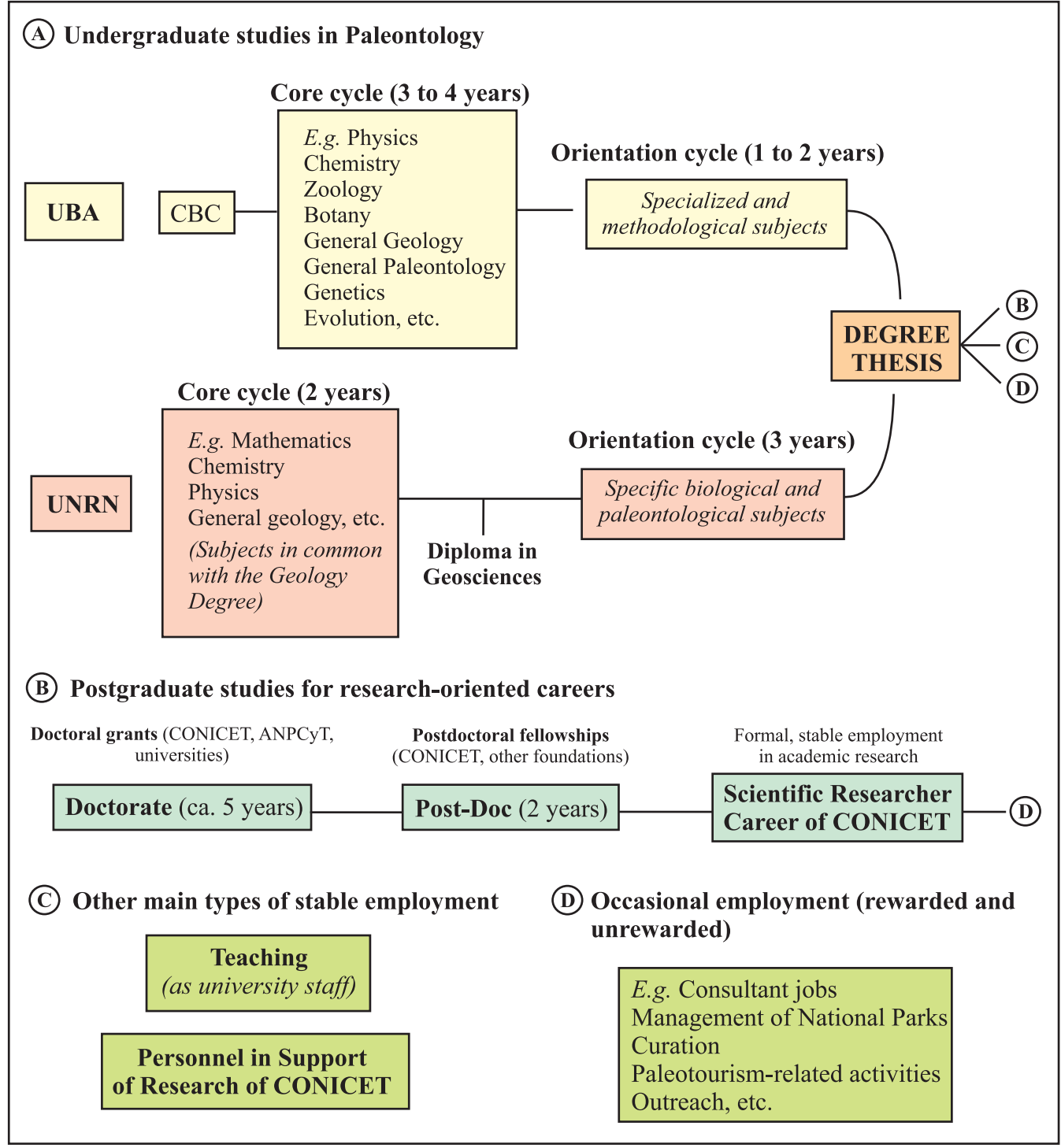

FIGURE 3. Flow chart summarizing the academic career for paleontologists in Argentina: schematic representation of the undergraduate and postgraduate studies and employment possibilities.

mon. In 2011 there were 11 foreign students enrolled in paleontology in the UBA (C.G.P.E.I., 2011), including people from Chile, Colombia, Peru, Costa Rica and Ecuador. However, a new degree has been created in Mexico, in the Humanist University of the Americas (Universidad Humanista de las Américas, UHA), and it has been running since September 2010, with already three graduates and 12 enrolled students to this date (Peña Ponce, personal commun., 2014). Also, a postgraduate degree with a tuition fee has been created this year in the Austral University of Chile (Universidad Austral de Chile, UACh), offering a two-year program for a limited number of students, who must be graduates in biology, geology or archaeology (Moreno, personal commun., 2014). This is excellent news since in Latin America there is a lot of paleontological ground to cover and more paleontologists are needed; these new degrees and specializations will hopefully give more impulse to the discipline in Latin America.

\section{Grants and employment}

The most stable and the commonest employment for paleontologists in Argentina is academic research, or research plus teaching. As is the general rule worldwide, it is required to earn a Ph.D. before applying for a research position within CONICET. Fortunately, CONICET, UBA and ANPCyT all provide fellowships (stipends) for graduates wish- 


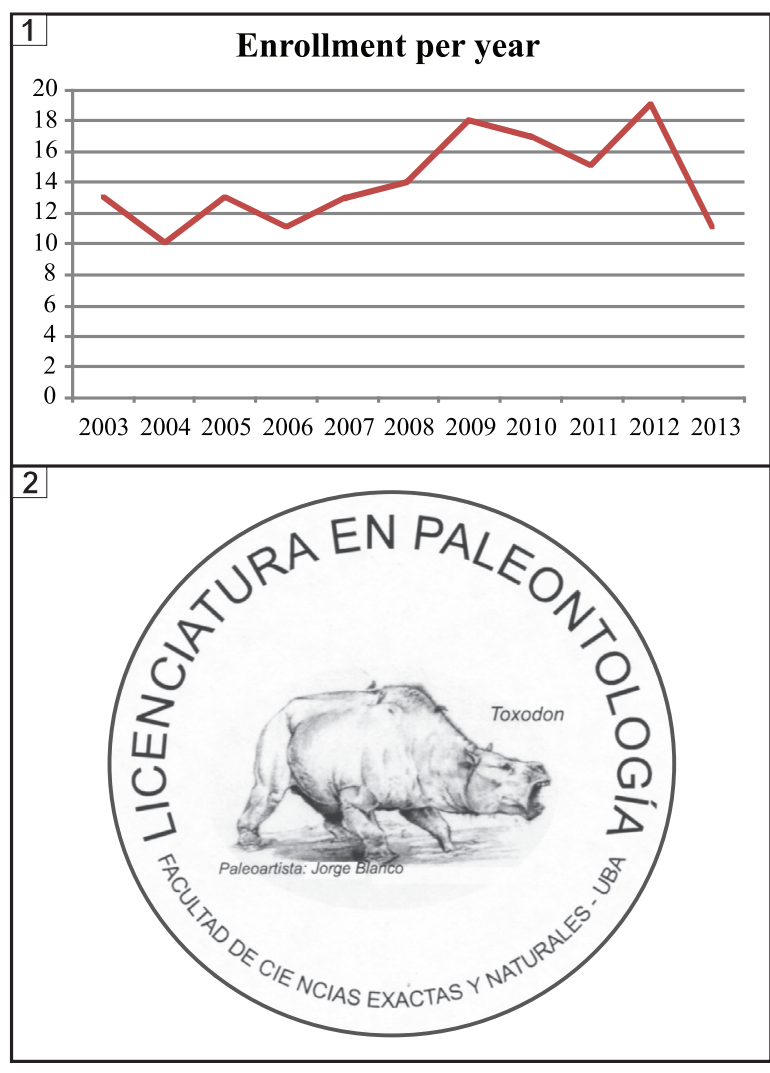

FIGURE 4. 1. Enrollment in the Paleontology Degree in the University of Buenos Aires in the period 2003-2013. Source: DOV (2013). 2. Logo of the Paleontology Degree of the UBA. Courtesy of M. Beatriz AguirreUrreta.

ing to pursue a Ph.D. There is no formal Ph.D. in paleontology yet, so thus far graduates have enrolled either in geology or biology postgraduate programs, which accept paleontological projects. Postdoctoral fellowships are available though only through CONICET and in a more reduced number than doctoral fellowships. Applicants to the Scientific Researcher Career of CONICET (CIC) commonly spend five to seven years as graduate students and/or postdoctoral fellows, with one or more of these fellowships.

Applications for the $\mathrm{CIC}$ are evaluated by a group of consultant peers (MINCyT, 2005a,b, 2010). Furthermore, CONICET researchers are regularly evaluated by peers and must pass periodical reports in order to sustain a given category (there are five main CIC categories; P.N.A., 1976) or to apply for a promotion.

Between 2004 and 2008, approximately 25\% of the CONICET researchers within the Earth, Water and Atmospheric Sciences Area worked in varied paleontological subjects. Moreover, the number of graduate students that were given stipends to initiate their doctoral studies in paleontological projects doubled between 2004 and 2013.

Another stable position can be obtained as Personnel in Support of Research Career (CPA, also of CONICET). The CPA includes both professionals and non-professionals involved in a great variety of tasks related to research, such as preparation of rocks samples and fossils, assistance in fieldwork, laboratory work, maintenance of equipment, administrative tasks, etc. Some may actively participate in research as well. These personnel work under the supervision of a researcher or research group. The CPA career is similar to the $\mathrm{CIC}$ in having several categories with different requirements and responsibilities and the opportunity to apply for promotions as well.

Many researchers also hold teaching positions within universities. The teaching job system differs across universities, but in many faculties of the UBA and in other universities as well, all teaching positions are assigned through open selection.

Although there is an official paleontological association in Argentina (APA) there is no professional organization of paleontologists yet, nor a professional license in paleontology. Paleontologists are needed for different kinds of private and governmental consultation, but are only rarely contacted directly by these potential employers. It is thus desirable that the profession became more widely known to the public so that both public and private organizations will hire paleontologists.

As is evident from this account of job possibilities, employment offers for paleontologists are dominantly issued from government agencies, with the private sector having a limited participation. There are some environmental consultants hiring paleontologists as permanent employees, but most other involvement of private businesses with paleontology is related to oil companies requiring micropaleontologists, palynologists, or other professionals specialized in groups with biostratigraphic value. Though common, these are not stable incomes, but temporary contracts.

Many positions that are directly related to the discipline, but that have been until now occupied by other professionals, should begin to be filled by paleontologists. Examples include administration and management of national parks with important paleontological content, curation of collections in museums throughout the country, paleotourism, and public outreach. There is much to do in this respect and only time and enthusiasm will tell how far paleontologists can go as new graduates start 
exploring career paths and as their work becomes more widely known.

\section{PALEONTOLOGICAL HERITAGE PROTECTION}

Efforts to provide legal safeguards to the paleontological and archaeological heritage of Argentina's legal system date back to the mid nineteenth century. They include specific laws as well as regulations in the Argentinian Constitution and Civil Code.

As early as 1863 , the government of the Buenos Aires province acknowledged the importance of protecting the fossil remains under its jurisdiction from export outside the country. A decree was issued stating that it was forbidden to collect fossils without a permit by the government, under monetary penalty (Camacho, 1971: p. 38).

Nevertheless, the first attempt of protection of this heritage at a national level dates back to 1913 , when Act $N^{\circ} 9080$ Archaeological Ruins and Sites (H.C.N.A., 1913; P.N.A., 1921) was enacted. This law claimed that the archaeological and paleontological remains of scientific interest were the property of the federal government. It also regulated the exploration and exploitation of the sites, by means of work permits that were only to be issued to scientific institutions without commercial purposes, and established limitations to the possession of remains or sites by individuals and private lands, considering the possibility of confiscation in special cases (Endere and Podgorny, 1997; Endere and Rolandi, 2007). Exportation was only allowed for duplicate items and always with due authorization. The Implementing Order of Act $\mathrm{N}^{\circ} 9080$, enacted in 1921, established the creation of an enforcement body (Sección de Yacimientos) that was to carry out the implementation of this law as well as organize and keep an official registry of all known sites and permits issued for research. It also decreed it was compulsory to report any finding of remains or sites to the authorities, either by particulars in private or public lands, or during private or public construction works. Endere and Podgorny (1997) and Endere and Rolandi (2007) summarized the historical context and the political circumstances that led to the enactment of this bill.

Unfortunately, in spite of all its provisions, this law achieved very little, since the federal government made scarce efforts to enforce it. Its initial resolve to protect paleontological and archaeological heritage was not translated into action and therefore the law was never really implemented (Endere and Podgorny, 1997; Endere and Rolandi, 2007). The enforcement body was never created and, over the 90 years during which this law was in force, the illegal collecting and commercialization of Argentinian fossils and archaeological pieces did not stop nor decline (Endere and Rolandi, 2007).

This situation of practical lack of protection led several Argentinian provinces to start developing their own legislation on the matter. Some of these regulations went against the national law, establishing regional jurisdiction over the paleontological and archaeological heritage (Endere, 2001, 2002; Endere and Rolandi, 2007). Although some of these regulations were innovative and introduced new forms of protection for our heritage, they also suffered from a lack of practical application (Endere, 2001, 2002).

After the modifications introduced first in the Civil Code in 1968, and subsequently in the Constitution in 1994, the status of the paleontological and archaeological heritage changed: the ownership passed from the federal government to the provincial governments and the government of the Autonomous City of Buenos Aires. The role of the federal government was now to dictate the general provisions for the protection of this heritage, whilst the provinces were now responsible for its care. Thus, many provinces updated their specific legislation on the matter (Endere and Rolandi, 2007; S.C, 2013), even as Act $\mathrm{N}^{\circ} 9080$ remained obsolete and contradicted some aspects of them and the reformed Civil Code and Constitution (Endere and Podgorny, 1997).

Eventually, in 2003 the current law for the protection of the archaeological and paleontological heritage was enacted, repealing Act $N^{\circ} 9080$ and seeking to significantly update the set of pertinent rules (Endere and Rolandi, 2007). Federal Act $\mathrm{N}^{\circ}$ 25743/2003 Protection of the Archaeological and Paleontological Heritage, (H.C.N.A., 2003) protects, preserves and regulates the activities involving all paleontological and archaeological remains and sites found in Argentinian territory, regarding them as part of the Cultural Heritage of the country (APA, 2014a) and is thereby protected and preserved so that it can be used for scientific and cultural purposes. The federal government exercises the legal safeguard of this heritage in the entire extent of the Argentinian territory, ensuring its preservation, scientific research and diffusion, as well as its protection and guardianship at the international level, arranging the return of archaeological and/or paleontological items to the country. The provincial governments and the government of the Autonomous City of Buenos Aires have the right of ownership and the duty of protection within their 
jurisdictions. Together, they must be able to coordinate actions that help develop a uniform legal framework and management throughout the territory.

Concerning specifically the field of paleontology, the law states that the paleontological heritage includes the organisms that lived in the geological past or their parts or evidences of their life activities, and every natural concentration of fossils in rocks or sediments exposed on or below the surface of the Nation's territory or under the Nation's territorial waters.

Act $N^{\circ} 25743$ establishes that the powers of the federal government are exercised by the National Enforcement Authorities (AANs, Autoridades de Aplicación Nacional de la Ley 25743) of each discipline, which are the competent agencies responsible for the application of this law at the national level. The Bernardino Rivadavia Argentinian Museum of Natural Sciences (Museo Argentino de Ciencias Naturales 'Bernardino Rivadavia') or MACN is the AAN with respect to the paleontological heritage (H.C.N.A., 2003; Parma et al., 2012) and is in charge of the organization and keeping of the National Registries of Paleontological Sites, Collections and Remains, and of First Offenders and Recidivists (Parma, 2010). It is entitled to authorize loans and transportation of fossils out of the country and promote the return of Argentinian fossils currently outside the country (APA, 2014a). It should also cooperate and coordinate actions with the competent agencies at the provincial level.

The roles of the provincial governments and the government of the Autonomous City of Buenos Aires are: 1) to create a competent agency responsible for the application of Act $\mathrm{N}^{\circ} 25743$ at the provincial level; 2) to organize their respective registries following the model of the AAN; 3) to issue work permits for scientific exploration and collection of fossils; 4) to grant loans and authorize transit of materials within the Argentinian territory; 5) to create local offices; and 6) to communicate periodically to the AAN the work permits issued, the loans and transports authorized, and the new entries to the registries.

The most prominent points of Act $\mathrm{N}^{\circ} 25743$ are the detailed rules introduced for the registry of sites and collections, the duties of the scientific researchers for the application to licenses, the duties of the owners of private lands where archaeological and paleontological sites were to be discovered, the obligation to report any type of finding of fossils or archaeological objects or sites, be it by particulars or during the course of public or private works (Endere, 2002), and the duties of the private owners of archaeological and paleontological collections or items.

In order to comply with the terms of Act $\mathrm{N}^{\circ}$ 25743 , all paleontologists planning to undertake fieldwork in a particular area of interest must formally request a work license to the competent agency of the jurisdiction in which that study area is located, proving their affiliation with an academic institution, stating expressly their exclusively scientific interest, establishing the geographical limits of the study area and the approximate dates and/or duration of the fieldworks, and providing a summary of their research project in the area stating hypothesis, objectives, methodology, and logistics (Figure 5). Foreign researchers wishing to carry out paleontological fieldworks in Argentinian territory must take the same steps and include an official written proof of their association with an Argentinian public university or scientific institution. After returning from the field, all licensees must submit the fossils collected for inspection by the competent agency of the jurisdiction, after which they can request a permission of temporary possession of the materials for two years for study purposes-although it can be extended in justified cases. Once this period is completed, the materials must be returned to their jurisdiction to be kept in a public repository. Should the materials be transferred temporarily to a different jurisdiction within the territory of Argentina for study and/or exhibition purposes, an authorization must be obtained from the competent local agency (Figure 5). For transfers outside the country, the permission must be issued by the AAN. In all cases, their restitution to their place of origin must be guaranteed.

The aforementioned steps and requirements are intended as measures to prevent the illegal exploitation and trafficking of paleontological and archaeological sites and remains, respectively. However, since it was enacted, Act $N^{\circ} 25743$ has not been immune to criticism. For instance, it has been said that this set of procedures hampers the work of researchers (Riccardi, 2005), and that it worsens an already inefficient bureaucratic network (Tonni, 2005). And even though the law may appear as an opportunity to create new jobs for paleontologists, related for instance with the registries of collections and sites or the evaluation of permit requests, this seems unlikely, since the local competent agencies may only rarely engage professional paleontologists (Beglieri and Massa, 2004). Other criticisms have been aimed at the 


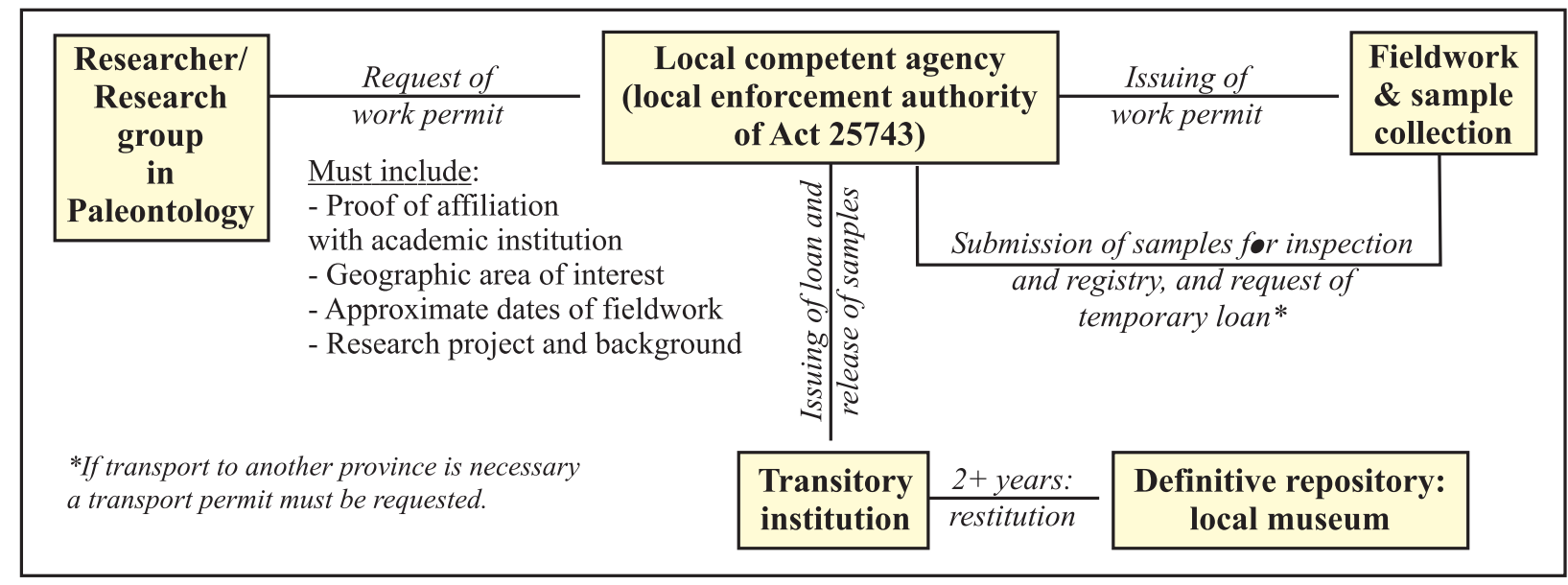

FIGURE 5. Flow chart of the mandatory steps for paleontological fieldwork in Argentina, and the treatment of fossils specimens according to Act $\mathrm{N}^{\circ} 25743$.

deficient wording of the act's text (Endere, 2002) and, which is far worse, at its unconstitutional nature for not complying with the Argentinian Constitution and Civil Code (Beglieri and Massa, 2004). In fact, Act № 25743 was amended in 2011 to specifically fix these two last issues (H.C.N.A., 2011).

It has also been said that this law interferes with the right to the private property (Beglieri and Massa, 2004) by supposedly enabling spontaneous confiscations of private collections, and thus hindering the participation of private collectors in matter of heritage and criminalizing them. Nevertheless, it must be said that Act $\mathrm{N}^{\circ} 25743$ sets very clear rules regarding the duties of individuals in possession of paleontological or archaeological collections acquired prior to its enactment. Under no circumstance are they to be criminalized for the sole possession of fossils or archaeological objects, providing that they complied with the rule of reporting their collections to the National Registries within a 90-day period from the date of enactment of Act $\mathrm{N}^{\circ} 25743$. Following the reporting of the collection, the private collector retains its possession. Only when after this term expired and the collector failed to report his/her possessions, it shall be presumed that a person holding such collection came into its possession illegally, which will bring about its confiscation.

Criticism from the Argentinian paleontological community has been aimed mainly at the inefficiency of the bureaucratic system established by the local competent agencies, meaning that in some cases they are under-prepared to carry out their tasks. Some setbacks that were identified are: problems with the issuing of licenses for field- works-refusals, delays - that cause researchers to have to cancel or postpone fieldtrips, problems with the access to collections housed in different repositories, and overlapping of research projects and study areas between different research groups (Roundtable on Heritage, 2010; Second Workshop on Heritage, 2010).

A major concern of a great part of the Argentinian paleontological community is the illegal trafficking of fossils that survives in spite of the current legislation. In 2003, the Argentinian Committee for the Prevention and Fight Against the Illegal Trafficking of Cultural Assets (Comité Argentino para la Prevención y Lucha contra el Tráfico llegal de Bienes Culturales) was created, being formed by the National Enforcement Authorities in paleontology and archaeology, INTERPOL, the Argentinian National Gendamerie (Gendarmería Nacional Argentina), the Argentinian Airport Security Police (Policía de Seguridad Aeroportuaria), the Argentinian Naval Prefecture (Prefectura Naval Argentina) and the Argentinian General Customs Administration (Administración General de Aduanas), amongst other institutions of the federal government (Endere, 2002). Their main goal is to join forces in order to stop illegal trafficking and to promote the implementation of national legislation and international agreements on the matter (Endere and Rolandi, 2007). One of the accomplishments of this committee was the publication of a Red List (INAPL and MACN, 2005) of endangered paleontological and archaeological heritage. All the institutions that form the committee cooperate with each other in disseminating information and raising awareness to the community on the matter of heritage, and also organizing courses, workshops and 
talks to help train the non-specialists working with the enforcement authorities. The committee has already made efforts for the safe return of paleontological remains illegally transferred outside the country (Endere, 2010; Parma, 2010; Parma et al., 2012).

In conclusion, the Argentinian paleontological community agrees, at a large extent, that the protection of the paleontological heritage is crucial, and at the same time it is interested in the matter and actively involved in it. It is also deeply concerned with the problem of the illegal trafficking. Therefore, the current legislation and the concurrent efforts of the federal and provincial governments and the national security forces represent the cornerstone upon which to continue working so that the paleontological heritage can give its full potential both to the science and to the Nation's culture.

\section{COLLECTIONS}

\section{Public and private repositories}

The Bernardino Rivadavia Argentinian Museum of Natural Sciences (MACN) shelters the six National Paleontological Public Collections: Ameghino (fossil vertebrate specimens originally studied by Florentino Ameghino), Paleobotany, Paleoinvertebrates, Paleopalynology, Paleovertebrates, and Ichnology, with a total of nearly 106,000 specimens (Ramírez, 2012; MACN, 2014). These collections include large repositories of different types of fossils coming from all around the country. Particularly, the Paleovertebrates collection includes the most important assemblage of South American dinosaurs.

Other institutions which house public fossil collections are mainly museums, e.g., La Plata Museum (Museo de La Plata, La Plata, Buenos Aires province), Egidio Feruglio Paleontological Museum (Museo Paleontológico Egidio Feruglio, Trelew, Chubut province), Dr. Arturo Umberto Illia Provincial Museum of Natural Sciences (Museo Provincial de Ciencias Naturales Dr. Arturo Umberto Illia, Córdoba city, Córdoba province), and universities, e.g., UBA, National University of Córdoba (Universidad Nacional de Córdoba, UNC) and National University of San Juan Universidad Nacional de San Juan, UNSJ).

A few private collections exist. Some are under the responsibility of private institutions, e.g., Félix de Azara Natural History Foundation (Fundación de Historia Natural Félix de Azara), while others are held by individuals. Many of these insti- tutions have digital catalogues, for example the MACN, although none of them currently have online access. Therefore, information on specific specimens is difficult to obtain without a direct inquiry to the curators.

\section{Local collections in foreign countries}

The Argentinian paleontologist often faces the issue of having to travel abroad in order to examine local, frequently type materials vital for his/her research topic. Several collections of Argentinian fossils are kept in museums and other scientific institutions around the world, especially in Europe and the USA. This relative dispersion is the result of several geological-paleontological expeditions carried out by foreign universities or oil companies, between the second half of the nineteenth century and the first half of the twentieth century, usually aimed at making the first discoveries in a hitherto poorly explored area. For example, the Princeton University Expeditions to Patagonia (Argentina and Chile, 1896-1899) led by John B. Hatcher collected large amounts of Mesozoic and Cenozoic fossil vertebrates, invertebrates and plants, that are presently kept in the Yale Peabody Museum of Natural History (vertebrates) and the Paleontological Research Institution (invertebrates, pars). Some of the foreign scientific expeditions that collected Argentinian fossils took place prior to the first national legislation protecting the paleontological heritage (1913), others when it was not enforced.

Fortunately, many Argentinian fossils are well maintained and curated in foreign institutions. But, at the same time, there are others, particularly in Europe, which suffered damage or went missing, for instance, during the Second World War.

\section{LOCAL SOCIETIES AND JOURNALS}

\section{The Argentinian Paleontological Association (APA)}

The Argentinian Paleontological Association (Asociación Paleontológica Argentina, APA) is a scientific, non-profit, non-governmental organization that promotes and supports the development of the discipline in the country. It is a renowned, prestigious institution that brings together the professional paleontologists and geologists of Argentina as well as the students of the careers in paleontology and geology, and the amateur (Figure 6.1). APA also publishes the scientific journal Ameghiniana and the Special Publications, a non- 


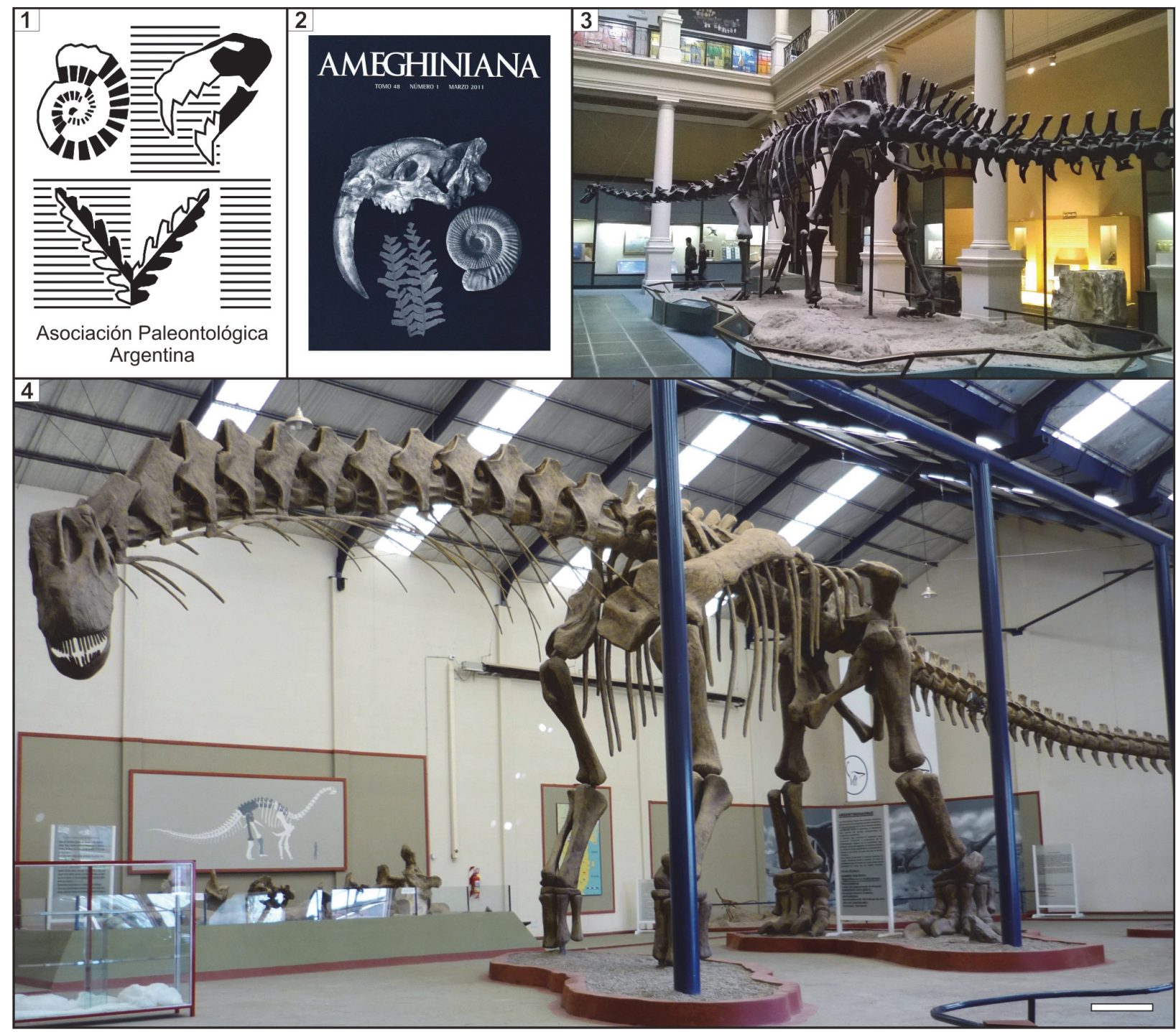

FIGURE 6. 1. Logo of the Argentinian Paleontological Asociation (APA). 2. Front cover of an Ameghiniana issue (Vol. 48, No1). 3. Diplodocus carnegii Hatcher in the La Plata Museum. Photo by Eliana Coturel. 4. Argentinosaurus huinculensis Bonaparte and Coria in the Carmen Funes Municipal Museum. Graphic scale $=1 \mathrm{~m}$. Photo by the authors.

periodic journal for the publishing of specific topics and the contributions from scientific meetings.

It was founded in 1955 by a group of specialists from different scientific institutions in Buenos Aires and La Plata, who established a provisional Executive Committee (Stipanicic, 2005). Two years later, a new Executive Committee was elected in assembly, and since then, a new one is chosen every two years.

The main purposes of the APA, deriving from its Statute (APA, 1978), are as follows: 1) to reunite all those interested in Argentinian paleontology and stratigraphy; 2) to contribute to the organization and development of paleontological activities in
Argentina; 3) to organize periodic meetings of scientific communication and to sponsor other paleontological and/or stratigraphic scientific meetings; 4) to connect amateur paleontology enthusiasts and fossil collectors with professional paleontologists and research institutions; 5) to contribute to the protection and care of the paleontological collections and sites; 6 ) to encourage the dissemination of paleontological knowledge throughout society; 7) to edit a scientific journal covering the whole spectrum of paleontological and stratigraphic research; and 8) to promote the organization of specialization courses on paleontology and other related subjects (APA, 2014b). 
The APA has four offices-with the head office in Buenos Aires-and 12 branches within the Argentinian territory, plus two branches abroad-in Uruguay and the USA (APA, 2014c).

Every year, in a different city of the country, the association organizes a scientific meeting (Reunión de Comunicaciones de la Asociación Paleontológica Argentina) to promote the communication of research results amongst members. Additionally, the association sponsors other local paleontological meetings, as the Argentinian Congress of Paleontology, the Argentinian Conference on Vertebrate Paleontology, the Argentinian Symposium on the Jurassic, and the Argentinian Symposium on Paleobotany and Palynology amongst others.

As regards the legislation on paleontological heritage, the APA is not empowered to act as an enforcement body (Roundtable on Heritage, 2010). However, it is actively involved in the matter and presently it is part of the Advisory Commission of the National Enforcement Authority of Act $\mathrm{N}^{\circ}$ 25743 (Comisión Asesora de la Autoridad de Aplicación Nacional de la Ley $N^{\circ} 25743$ ) on paleontological heritage. In this line, the association has organized forums of discussion on this topic for the paleontological community on the occasions of the ninth and tenth Argentinian Paleontological Congress (APA, 1982; Second Workshop on Heritage, 2010).

The APA invites and promotes the membership of foreign paleontologists, and especially encourages the collaboration of foreign researchers with Argentinian colleagues. To this end, in 1982 the association elaborated a set of ethical principles for paleontological research on Argentinian material by or in collaboration with foreign researchers (APA, 1982).

\section{Journals}

Ever since its founding, the APA had the intention to publish a journal specialized in paleontology. In 1957, the first number of Ameghiniana came out, named in honor of Florentino Ameghino. This was the first paleontological journal in South America, and was under the direction of Raúl Ringuelet (Damborenea, 2005). Ameghiniana today is a bimonthly journal that releases six issues per year (Figure 6.2); it currently only accepts papers written in English (Ameghiniana's Editorial Committee, 2014). There are over 50 published volumes. In the year 2000, it was included in the indexing system of the Institute of Scientific Information (ISI), and its contents are depicted in the majority of international indices (Damborenea, 2005). This has made it the most important paleontological journal in Latin America. It comprises papers of all sorts of paleontological topics, as well as occasional abstract volumes of regional meetings. The journal is a reflection of the development of paleontology in the country, shown by the increase over the years in the number of papers and topic diversity. The journal is currently in a process of expansion, updating, and editorial change (Pol, 2013).

Besides Ameghiniana, other publications nonspecialized in paleontology are responsible for the communication of papers on paleontological subjects in Argentina. The Argentinian Natural Sciences Museum Journal (Revista del Museo Argentino de Ciencias Naturales) was created in 1864 , and it is the oldest scientific publication in the country. This journal is also in process of modification and overhaul. The Argentinian Geological Association Journal (Revista de la Asociación Geológica Argentina) is another local journal that occasionally includes paleontological papers.

\section{SOCIAL ASPECTS AND IMPACT ON SOCIETY}

\section{Pre-university education}

In the 1970s, a new subject was incorporated to the high school curricula; it was called Evolution, Comparative Anatomy and Paleontology (Evolución, anatomía comparada y paleontología) (Massarini et al., 2007; Massarini, 2009). However, the reach of the effective implementation of this change cannot be determined. Two years later, the 1976 coup d'état installed a civic-military right-wing dictatorship. During that period, a different system existed for the training of natural science teachers for private education. That system, implemented in 1979, excluded the aforementioned subject and included as an objective that "school graduates understand nature as God's creation (Massarini et al., 2007; Massarini, 2009).

Evolutionary concepts were incorporated as part of biological subjects in education programs for elementary school (ages 6-12) and high school (ages 13-17) in 1995 and 1997, respectively. This occurred under pressure from ecclesiastic sectors, which drove to the reformulation of content related to evolution without any public debate or participation of the educational community (Gvirtz and Valerani, 1999). As in many Latin American countries, the religious diversity in Argentina is low, with Catholicism as the dominant religion. The presence alone of such topics in national educational 
programs does not guarantee that they will be taught, mainly because of the lack of updated training for teachers (Massarini et al., 2007). Nevertheless, unlike what happens in some parts of the USA (Gould, 1999), there is no open public opposition or debate on the teaching of evolution in schools.

Regarding Earth sciences in general, some concepts related to geological issues are addressed in national educational programs (CFE, 2011a,b, 2012). On a provincial level, some programs give these topics more importance. In the Buenos Aires province, for example, there is a subject called Earth Sciences (Ciencias de la Tierra) in the last year of high school. Nevertheless, general paleontological topics are only included as informative in discussions regarding geological time, geological history and tectonics (DGCE-PBA, 2014). It would be desirable to extend this subject, and the paleontological concepts, in particular, on a national level. Even when basic evolutionary concepts are included in middle school curricula, it might take time for their correct implementation. In a country of immense paleontological richness, transmission of paleontological knowledge remains somewhat undervalued in the educational system.

\section{Outreach}

Paleontological outreach is relatively recent in a national level. In spite of this, some Argentinian natural history museums have a long tradition in this field. The La Plata Museum stands out. Founded in 1884, it has been opened to the public since 1888. The museum has included a paleontology section since 1890 and it is famous worldwide for its large exhibition of Quaternary fossil mammals from the province of Buenos Aires. It was the first Argentinian museum to exhibit reconstructions of complete dinosaur skeletons, including a replica of the sauropod Diplodocus carnegii Hatcher, donated by the American tycoon Andrew Carnegie to various museums around the world (Figure 6.3; La Plata Museum, 2014).

The MACN, located in the city of Buenos Aires, was founded in 1812 (Asúa, 2012). It has a long paleontological tradition, with halls dedicated to dinosaurs, Quaternary mammals, fossil plants and the origin of birds. In other regions of the country there are younger museums, such as the MEF (Egidio Feruglio Paleontological Museum), founded in 1988 (MEF, 2012) in Trelew (Chubut province), and the Carmen Funes Municipal Museum (Museo Municipal Carmen Funes), founded in 1984 (Jozami, 2014) in Plaza Huincul (Neuquén province).

The main attractions of all these museums are dinosaur exhibitions (Figure 6.4), which provide the greatest magnet for the interest of the general public. All these institutions provide guided tours, especially for school students, so the connection between paleontological museums and the general non-scientific audience occurs at very early ages. During 2013, approximately 80000 school children visited the MACN (MACN Administration, personal commun., 2014). Most exhibits are somewhat outdated in certain aspects, such as the style of old curiosity cabinets, but at the same time they include some modern displays with a more scientific approach and a greater information quality, highlighting the most spectacular fossils. Often, the absence of direct contact between the exhibits and the scientists at these museums is noticeable (Ametrano et al., 2012). In most cases, less attention is given to disciplines not related to large vertebrates.

\section{Paleontology and tourism}

Apart from museums, there are other places where visitors are able to encounter fossils in Argentina. Paleontological tourism gained interest in the last decade. In 2006, the First International Symposium on Tourism and Paleontology took place in San Luis province. The subject has been discussed in other scientific meetings since then (e.g., Twenty-eighth Jornadas Argentinas de Paleontología de Vertebrados). Visiting areas rich in paleontological content, with or without an active participation of the public, is still not widespread in Argentina. Most ongoing projects are located in Patagonia or central-western Argentina. Some are very local examples while others are regional corridors (Perini and Calvo, 2005, 2008; GLR, 2014). They are mostly oriented towards vertebrate remains and are usually associated with already existing geoparks or natural reserves.

While the possibilities are numerous, paleontological tourism still remains underexploited in the country. To carry on this kind of initiative would entail to guarantee the control and protection of the heritage, as well as the lowest possible environmental impact (Apesteguía, 2014).

\section{SUMMARY AND FUTURE PROSPECTS}

Paleontology in Argentina has a long history. The first fossil discoveries date back to the mideighteenth century. The progress made in recent years indicates that the discipline continues to 
grow in the country and has promising future prospects.

Given than most of the scientific research done in Argentina is funded by government agencies, the future of paleontology (and many other scientific disciplines) in the country is directly dependent on whether or not the scientific progress of the country continues to be a national government's priority. For the moment, the funding of paleontological projects, the stable number of researchers in the area and the increment in the number of stipends for graduate students, all appear highly promising. The demand of CPA continues to grow and should be considered an interesting alternative to the CIC.

In the last 12 years, two formal degrees in paleontology were created in Argentina, including the first one in Latin America. The number of incoming students, both national and international, continues to be steady and the great majority of graduates have incorporated into the scientific system.

Countless fossils have been illegally taken from our country in the last 100 years. Under the updated, current law for protection of paleontological heritage, progress on the subject has been made, but a lot remains to be achieved. We believe that some of the problems arising from the implementation of the law are mainly bureaucratic. In a country of incredible landscape beauty and multicultural richness, the inclusion of paleontological sites in tourism remains mostly unexploited. The few ongoing projects show that this is a promising area which conveys employment opportunities and could also become a potential awareness tool in regard to paleontological heritage protection for local and foreign visitors.

\section{ACKNOWLEDGMENTS}

We are very grateful to Roy Plotnick for his kind invitation to write this commentary. His helpful and constructive editorial work greatly improved this contribution. CONICET and the Bunge and Born Foundation are acknowledged for the postgraduate grants given to the authors. The following persons and entities are deeply acknowledged:

- R. Misiac and C.A. Diego (Gerencia de Evaluación y Planificación, Dirección de Planificación y Evaluación Institucional; CONICET), for their assistance with data on CONICET grantees and researchers;
- M.B. Aguirre-Urreta (IDEAN-CONICET, UBA), for sharing bibliography and the UBA Paleontology degree logo;

- DOV (Departamento de Orientación Vocacional, FCEN-UBA), for providing data on the number of total and foreign students in the Paleontology degree (UBA);

- A. Pérez (UBA), for her help with understanding the actual controversy around CPI measurements in Argentina;

- S. Casadío (UNRN), for sharing information on the paleontology degree of the UNRN;

- V. H. Peña Ponce (UHA), for sharing information on the paleontology degree of the UHA (Mexico);

- K. Moreno (UACh), for sharing information on the master of paleontology degree of the UACh (Chile);

- G. Díaz (MACN, Administration) and V. Iglesias (MACN, Museology), for providing information about museum's visitors;

- E. Coturel (MLP), M. Longobucco (MACN), M. Miñana (MACN) and E. Vera (MACN), for supplying photographic material;

- APA and Ameghiniana's Directive Committee for granting permission to use images.

We would like to clearly state that the opinions and points of view expressed in this work are ours, and do not necessarily reflect those of our colleagues. This is contribution R-146 of the Instituto de Estudios Andinos Don Pablo Groeber (IDEAN).

\section{REFERENCES}

Aguirre-Urreta, M.B. and Camacho, H. 2011. Martín Doello Jurado y la enseñanza de la Paleontología en la Universidad de Buenos Aires. Revista de la Asociación Geológica Argentina, 68:329-336.

Aguirre-Urreta, M.B., Griffin, M. and Ramos, V. 2009. Darwin's geological observations in Argentina. Revista de la Asociación Geológica Argentina, 64:47.

ANPCyT (Agencia Nacional de Promoción Científica y Tecnológica). 2014. FAQs. FONCyT. agencia.mincyt.gob.ar/frontend/agencia/faq/3

Ameghiniana's Editorial Committee. 2014. Editorial guidelines. ameghiniana.org.ar/index.php/ameghiniana/about/submissions\#authorGuidelines

Ametrano, S., Podgorny, I. and Lopes, M.M. 2012. Buenos Aires, 1884. De cómo la fragilidad de unos esqueletos derrumbaron el proyecto de un Gran Museo Nacional. Revista del Museo Argentino de Ciencias Naturales, 14:167-174. 
APA (Asociación Paleontológica Argentina). 1978. Estatuto de la Asociación Paleontológica Argentina. www.apaleontologica.org.ar/?cat=55\&lang=en

APA (Asociación Paleontológica Argentina). 1982. Ethical principles and rules for paleontological research on argentine material by or in collaboration with foreign researchers. apaleontologica.org.ar/ ?cat=7\&lang=en

APA (Asociación Paleontológica Argentina). 2014a. Patrimonio Paleontológico. apaleontologica.org.ar/ ?cat $=80$ \&lang=es

APA (Asociación Paleontológica Argentina). 2014b. Main goals. apaleontologica.org.ar/?cat=54\&lang=en

APA (Asociación Paleontológica Argentina). 2014c. Sedes y delegaciones. apaleontologica.org.ar/ ?cat=56\&lang=en

Apesteguía, S. 2014. Turismo paleontológico: una propuesta de reactivación para localidades pequeñas de Patagonia. $28^{\circ}$ Jornadas Argentinas de Paleontología de Vertebrados. Resúmenes, p. 56. Zapala y El Chocón.

Archangelsky, S. 2005. La Paleobotánica en Argentina y su desarrollo durante los últimos 50 años. Asociación Paleontológica Argentina, Publicación Especial, 10:37-49.

Asúa, M. de. 2012. Dos siglos y un museo, p.13-69. In Penchaszadeh, P. (ed.), El Museo Argentino de Ciencias Naturales 200 años. Buenos Aires.

Beglieri, A. and Massa, L. 2004. Patrimonio arqueológico, paleontológico e histórico; reflexiones éticojurídicas y reseña periodística: la Ley 27.543, su inconstitucionalidad. Diario Judicial (online; diariojudicial.com/).

Camacho, H. 1966. Invertebrados Fósiles. Eudeba, Buenos Aires.

Camacho, H.H. 1971. Las Ciencias Naturales en la Universidad de Buenos Aires. Estudio Histórico. Editorial Universitaria de Buenos Aires, Buenos Aires.

Camacho, H.H. and Longobucco, M. (eds.). 2008. Los Invertebrados Fósiles. Vazquez Mazzini Editores, Buenos Aires.

CFE (Consejo Federal de Educación). 2011a. Ciclo Básico de Educación Secundaria. Ciencias Naturales. Núcleo de Aprendizajes Prioritarios. Ministerio de Educación.

CFE (Consejo Federal de Educación). 2011b. Marcos de Referencia. Bachiller en Ciencias Naturales. Educación Secundaria Orientada. Resolución CFE $n^{\circ}$ 142.

CFE (Consejo Federal de Educación). 2012. Núcleo de Aprendizajes Prioritarios. Ciclo Orientado de Educación Secundaria. Ciencias Naturales. Resolución CFE $\mathrm{n}^{\circ} 180$.

C.G.P.E.I. (Coordinación General de Planificación Estratégica e Institucional-UBA). 2011. Resultados Finales, Censo de Estudiantes 2011. uba.ar/institucional/censos/Estudiantes2011/estudiantes\%202011.pdf
CONICET. 2013. Estipendio de beca según zona de trabajo, agosto 2013. web.conicet.gov.ar/documents/ 11773/d7faf311-872b-4b9b-8c54-041534f39f76.

Damborenea, S. 2005. Historia de Ameghiniana. Asociación Paleontológica Argentina, Publicación Especial, 10:23-34.

Darwin, C. 1846. Geological Observations on South America. Being the Third Part of the Geology of the Voyage of the Beagle, under the Command of Capt. Fitzroy, R.N. during the Years 1832 to 1836. Smith Elder and Co., London.

DGCE-PBA (Dirección General de Cultura y Educación Provincia de Buenos Aires). 2014. Ciencias de la Tierra. Diseño Curricular para la Educación Secundaria, $5^{\text {to }}$ año. fmmeducacion.com.ar/Sisteduc/Buenosaires/Secundario/

5to_CienciasNaturales_Orientadas/ciencias_de_la_tierra.pdf

d'Orbigny, A. 1842. Voyage dans l'Amérique Méridionale (le Brésil, la République Orientale de l'Uruguay, la République Argentine, la Patagonie, la République du Chili, la République du Bolivia, la République du Pérou), exécuté pendant les années 1826, 1827, 1828, 1829, 1830, 1831, 1832 et 1833. Tome 3, 4ème. partie, Paléontologie. P. Bertrand, Paris; Ve. Levrault, Strasbourg.

DOV (Dirección de Orientación Vocacional, FCEN-UBA). 2013. Informe de actividades y de matrícula de ingresantes 2012. exactas.uba.ar/download.php?id=2897

Endere, M.L. 2001. Patrimonio Arqueológico en Argentina. Panorama actual y perspectivas futuras. Revista de Arqueología Americana, 20:143-158.

Endere, M.L. 2002. Nuevas tendencias en materia de legislación provincial del Patrimonio Arqueológico en la Argentina. Anclajes, 6:295-327.

Endere, M.L. 2010. Protección legal contra el tráfico ilícito de bienes paleontológicos en Argentina. Roundtable on Heritage, XXV Argentinian Conference of Vertebrate Paleontology. San Luis. docs.google.com/file/d/ OB6WiZF224oukMzM0M2MyY2UtZWIyYS00Mjc1LTg3ZjgtMmE3YzYzNjBhNmU3/ edit?hl=es\&pli=1

Endere, M.L. and Podgorny, I. 1997. Los Gliptodontes son argentinos. La Ley 9080 y la creación del Patrimonio Nacional. Ciencia Hoy, 7:54-59.

Endere, M.L. and Rolandi, D. 2007. Legislación y gestión del Patrimonio Arqueológico. Breve reseña de lo acontecido en los últimos 70 años. Relaciones de la Sociedad Argentina de Antropología, 22:33-54.

Fernícola, J.C., Prieto, A.R., Lazo, D.G. (eds.). 2011. Vida y obra de Florentino Ameghino. Asociación Paleontológica Argentina, Publicación Especial 12, Buenos Aires.

GLR (Gobierno de La Rioja). 2014. Ruta de los dinosaurios. Downloaded July 2014, larutadelosdinosaurios.com/

Gould, S.J. 1999. Rocks of Ages: Science and Religion in the Fullness of Life. Ballantine Books, New York. 
G.R.H.-CONICET (Gerencia de Recursos HumanosCONICET). 2012a. Investigadores por Gran Área de Conocimiento 2012. www.conicet.gov.ar/recursoshumanos/?graficoid=21282

G.R.H.-CONICET (Gerencia de Recursos HumanosCONICET). 2012b. Recursos humanos por año y provincia, 2003/2007/2012. conicet.gov.ar/recursoshumanos/?graficoid $=21251 \#$

G.R.H.-CONICET (Gerencia de Recursos HumanosCONICET). 2013. Becarios por Gran Área de Conocimiento 2012. www.conicet.gov.ar/becarios/?graficoid $=21312$

Gutiérrez, J. 1866. La paleontología en las colonias españolas. Revista de Buenos Aires, 11:100-114.

Gvirtz, S. and Valerani, A. 1999. "Pasado y presente de las teorías de la evolución en la escuela: entre la política y la ciencia". Novedades Educativas 101.

Harrington, H. 1937. On some Ordovician fossils from northern Argentina. Geological Magazine, 74:97-124.

H.C.N.A. (Honorable Congreso de la Nación Argentina). 1913. Ley 9080. Ruinas y yacimientos arqueológicos. Buenos Aires.

H.C.N.A. (Honorable Congreso de la Nación Argentina). 2001. Ley 25467 - Ciencia, Tecnología e Innovación. Buenos Aires.

H.C.N.A. (Honorable Congreso de la Nación Argentina). 2003. Act $^{\circ}$ 25743. Protection of the archaeological and paleontological heritage. Buenos Aires. v2012.cultura.gob.ar/traficoilicito/pdf/ley_25743_protec_patrimonio_eng.pdf

H.C.N.A. (Honorable Congreso de la Nación Argentina). 2007. Ley 26338 - Modificación de la Ley de Ministerios. Buenos Aires.

H.C.N.A. (Honorable Congreso de la Nación Argentina). 2008. Ley 26421 - Raíces. Buenos Aires.

H.C.D.N. (Honorable Cámara de Diputados de la Nación). 2009 to 2014. diputados.gob.ar/proyectos/ resultado.html?palabras=precios+al+consumidor.

H.C.N.A. (Honorable Congreso de la Nación Argentina). 2011. Protección del Patrimonio Arqueológico y Paleontológico. Buenos Aires.

INAPL (Instituto Nacional de Antropología y Pensamiento Latinoamericano) and MACN (Museo Argentino de Ciencias Naturales Bernardino Rivadavia). 2005. Red List of Argentine Archaeological and Paleontological Objects at Risk. v2012.cultura.gob.ar/traficoilicito/pdf/Red_List.pdf

INDEC (Instituto Nacional de Estadística y Censos). 2014. indec.gov.ar/

Jozami, K. 2014. "La pasto verde" y los dinosaurios. Downloaded July 2014. interpatagonia.com/paseos/ carmen_funes/

La Plata Museum. 2014. Historia. Downloaded March 2014. museo.fcnym.unlp.edu.ar/historia

MACN (Museo Argentino de Ciencias Naturales Bernardino Rivadavia). 2014. Colecciones del MACN. macn.secyt.gov.ar/investigacion/inv_coleccionesmacn.php\#paleontologicas
Massarini, A. 2009. La teoría evolutiva como hilo conductor en la enseñanza de la biología. Su tardía incorporación a la educación básica y media en Argentina. Primera Reunión de Biología Evolutiva del Cono Sur. A 150 años de la publicación de "El Origen de las Especies" de Charles Darwin. Simposio: Evolución y Educación. FCEN, UBA. Buenos Aires.

Massarini, A., Schnek, A., Piccinali, R. and Folguera, G. 2007. Democratizar el conocimiento científico: criterios y estrategias para un cambio en la enseñanza de las ciencias, 8 pp. Cuarto Congreso Comunicación Social de la Ciencia. Cultura Científica y Cultura democrática. MEyC de España, CSIC y FECYT. Madrid.

MECT (Ministerio de Educación, Ciencia y Tecnología de la Nación Argentina). 2006. Plan Estratégico Nacional de Ciencia, Tecnología e Innovación 'Bicentenario' 2006-2010. Buenos Aires.

MEF (Museo Paleontológico Egidio Feruglio). 2012. Historia institucional. mef.org.ar/

MINCyT (Ministerio de Ciencia, Tecnología e Innovación Productiva). 2005a. Resolución $n^{\circ}$ 1046. mincyt.gob.ar

MINCyT (Ministerio de Ciencia, Tecnología e Innovación Productiva). 2005b. Resolución $n^{\circ}$ 1857. mincyt.gob.ar

MINCyT (Ministerio de Ciencia, Tecnología e Innovación Productiva). 2010. Resolución $n^{\circ}$ 2279. mincyt.gob.ar

MINCyT (Ministerio de Ciencia, Tecnología e Innovación Productiva). 2011. Argentina Innovadora 2020. Plan Nacional de Ciencia, Tecnología e Innovación. Lineamientos estratégicos 2012-2015. mincyt.gob.ar/ adjuntos/archivos/000/022/0000022576.pdf

MINCyT (Ministerio de Ciencia, Tecnología e Innovación Productiva). 2013. Report "Indicadores de Ciencia y Tecnología. Argentina 2011". mincyt.gob.ar/_post/ descargar.php?idAdjuntoArchivo $=24262$

Ottone, E.G. 2001. Los primeros hallazgos de plantas fósiles en Argentina. Asociación Paleontológica Argentina, Publicación Especial, 8:49-51.

Ottone, E.G. 2005. The history of paleobotany in Argentina during the 19th century, p. 281-292. In Bowden, A.J., Burek, C.V. and Wilding, R. (eds.), History of Paleobotany: Selected Essays. Special Publications 241, Geological Society, London.

Ottone, E.G. 2011. Historia de la paleobotánica en la Argentina durante el siglo XIX: científicos, exploradores y el país en exposición. Revista de la Asociación Geológica Argentina, 68:370-379.

Parma, S.G. 2010. El estado actual de la aplicación de la Ley $\mathrm{N}^{\circ} 25743$ a nivel nacional. Segundo Taller de Patrimonio de la Asociación Paleontológica Argentina 2010. Décimo Congreso Argentino de Paleontología y Bioestratigrafía y Séptimo Congreso Latinoamericano de Paleontología, La Plata. 
Parma, S.G., Paz, E.R., Garrido, J.L. and Roncarolo, M.B. 2012. Autoridad de Aplicación Nacional en Materia Paleontológica, p. 169. In Penchaszadeh, P.E. (ed.), El Museo Argentino de Ciencias Naturales, 200 años. MACN, Buenos Aires.

Pascual, R. 1981. Las investigaciones sobre vertebrados fósiles en Argentina después de los años 1960. Asociación Paleontológica Argentina, Publicación Especial, 1:23-27.

Perini, J.O. and Calvo, J.O. 2005. Turismo Paleontológico: una alternativa de ingresos a la Paleontología de Vertebrados. Congreso Latinoamericano de Paleontología de Vertebrados. Resumos, p. 200201. Museu Nacional, Universidade Federal do Rio de Janeiro.

Perini, J.O. and Calvo, J.O. 2008. Paleontological Tourism. An alternative income to vertebrate paleontology. Arquivos do Museu Nacional do Rio de Janeiro 66:285-289.

P.N.A. (Presidencia de la Nación Argentina). 1921. Decreto 211229/21 - Decreto Reglamentario de Ley 9080 de Ruinas y Sitios Arqueológicos. Buenos Aires.

P.N.A. (Presidencia de la Nación Argentina). 1976. Decreto 1572/76 - Ciencia y Tecnología - Carrera del Investigador Científico y Tecnológico y Carrera del Personal de Apoyo a la Investigación y Desarrollo. Escalafón. Buenos Aires.

P.N.A. (Presidencia de la Nación Argentina). 1996. Decreto 1661/96 - Consejo Nacional de Investigaciones Científicas y Técnicas. Buenos Aires.

P.N.A. (Presidencia de la Nación Argentina). 2007. Decreto 310/2007 - Consejo Nacional de Investigaciones Científicas y Técnicas. Buenos Aires.

Pol, D. 2013. Ameghiniana: presente y futuro. Reunión de Comunicaciones de la Asociación Paleontológica Argentina. Ameghiniana 50: Suplemento: R28.

Ramírez, M. 2012. ¿Por qué colecciones científicas?, p. 133-167. In Penchaszadeh, P. (ed.). El Museo Argentino de Ciencias Naturales 200 años. Buenos Aires.

Reig, O. 1961. La paleontología de vertebrados en la Argentina. Retrospección y prospectiva. Holmbergia, 6:67-128
Riccardi, A. 1981. Reseña de la historia de la Paleontología de Invertebrados en la Argentina. Asociación Paleontológica Argentina, Publicación Especial, 1:17-22.

Riccardi, A. 2005. La Paleontología de Invertebrados en la Argentina, 1955-2005. Asociación Paleontológica Argentina, Publicación Especial, 10:53-69.

Rocca, G. 2014. Más continuidades que ruptura. El Cable, 841:2-3. fcen.uba.ar/prensa/cable/2014/

Roundtable on Heritage. 2010. Twenty-fifth Argentinian Conference of Vertebrate Paleontology. San Luis. apaleontologica.blogspot.com.ar/2010/06/patrimonio-paleontologico-reflexiones.html

S.C. (Secretaría de Cultura, Presidencia de la Nación). 2013. Legislación Provincial en Materia Paleontológica. V2012.cultura.gob.ar/traficoilicito/ redlist.php\%3Fview=leg.html

Schávelzon, D. and Arenas, P. 1992. Los inicios de la Paleontología en Argentina. Todo es Historia, 295:37-49.

Second Workshop on Heritage. 2010. Argentine Paleontological Association. apaleontologica.blogspot.com.ar/2010/12/segundo-taller-depatrimonio.html

SIU (Sistema de Información General). 2011. Información Presupuestaria. informacionpresupuestaria.siu.edu.ar/DocumentosSPU/ Anuario\%20de\%20Estad\%C3\%ADsticas\%20Universitarias\%20-\%20Argentina\%202011.pdf

Stipanicic, P.N. 2005. Historial de la Asociación Paleontológica Argentina. Asociación Paleontológica Argentina, Publicación Especial, 10:15-19.

Tonni, E. 2005. El último medio siglo en el estudio de los vertebrados fósiles. Asociación Paleontológica Argentina, Publicación Especial, 10:73-85.

Top Universities. 2014. Universidad de Buenos Aires Overview. topuniversities.com/universities/universidad-de-buenos-aires/undergrad\#program

Wharton School (University of Pennsylvania). 2011. Knowledge@Wharton (online business analysis journal). knowledge.wharton.upenn.edu/article/argentinas-inflation-rate-in-the-eye-of-the-beholder/

World Review. 2014. worldreview.info/content/risinginflation-puts-pressure-argentine-currency 